\title{
Effect of Graded Levels of Nitrogen and Potassium on Yield and Quality of Sweet Potato (Ipomoea batatas L.)
}

\author{
M. Pushpalatha*, P.H. Vaidya and P.B. Adsul \\ Department of Soil Science and Agriculture chemistry, College of Agriculture, Latur \\ Vasantrao Naik Marathwada Krishi Vidyapeeth, Parbhani 431402 (M.S.) India \\ *Corresponding author
}

\begin{tabular}{|c|c|}
\hline \multicolumn{2}{|r|}{$A B S T A C T$} \\
\hline & \multirow{6}{*}{ 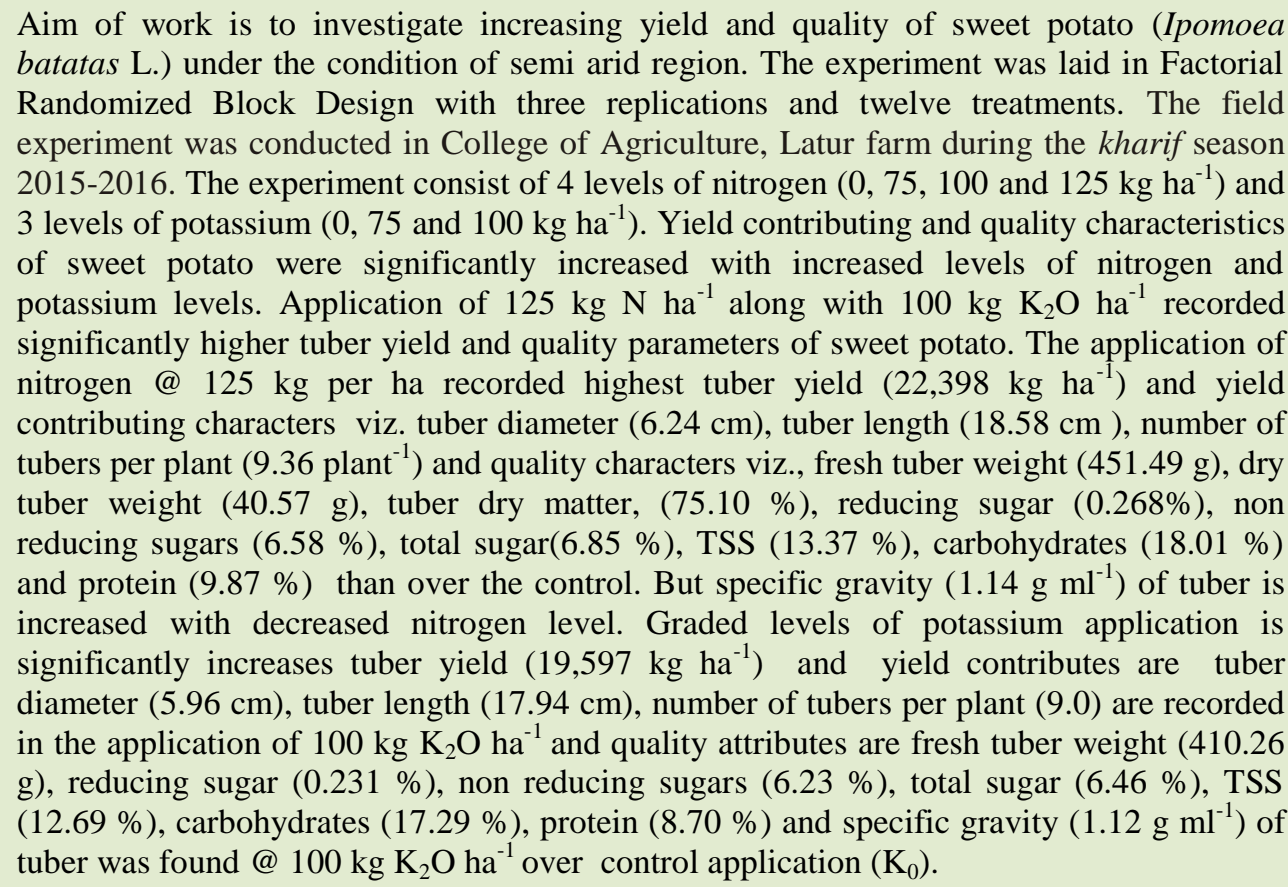 } \\
\hline Keywords & \\
\hline $\begin{array}{l}\mathrm{S} \\
\mathrm{N} \\
\mathrm{P} \\
\mathrm{Q} \\
\mathrm{S}\end{array}$ & \\
\hline Article Info & \\
\hline & \\
\hline & \\
\hline
\end{tabular}

\section{Introduction}

Tuber crops are the third important food crops in the world after cereals and legumes. It is dicotyledonous plant belongs to the family convolvulaceae. Sweet potato is a starchy root crop grown in tropical and subtropical countries like China, USA, India, Japan, Indonesia, Philippines, Thailand, Vietnam, and Nigeria. In India it is cultivated in almost all the states. Sweet potato is considered as a 'poor man's rich food' in many parts of India. In India sweet potato is largely grown in three states Orissa, Uttar Pradesh, and West Bengal. Sweet potato is a vegetative propagated crop and it is excellent source of complex carbohydrates, high antioxidants, vitamins A, $\mathrm{C}$ and rich in several essential macro and 
micronutrients. Considerable efforts have been made recently to promote sweet potato and to create awareness among the farming communities. The crop is known as a highly tolerant tuberous root crop to high temperatures, poor soils Uwah et al., (2013).

Sweet potato production can be increased substantially through the proper use of fertilizer. Nitrogen is most important major plant nutrient; it helps for growth and development of crop, most important macronutrients in the formation of yield and quality of vegetables, great importance as a constituent of numerous organic molecules in plant such as proteins, nucleic acids and alkaloids, enzymes, chlorophyll-a, chlorophyll-b, certain acid of nucleus and certain hormones and its content is associated with the leaf relative chlorophyll content which affects photosynthesis. Nitrogen is the "Motor of plant growth". Unbalanced excess fertilizers in crops will decrease quality of crops particularly storage ability (FAO and IFA, 2000). Nitrogen is an important factor in determining the yield and nutrient composition of root tubers, especially sweet potato Ukom et al., (2009).

Potassium plays an important role in relation to water, energy, translocation of assimilates, photosynthesis, protein and starch synthesis, metabolic processes, grain yield or seed formation, improving quality vegetable in terms of size, shape, color, taste, shelf life and fiber quality. Imparting resistance against environmental stresses and resistant to pest and diseases. Potassium deficiencies can limit the accumulation of crop biomass. This is attributed to that, potassium increases the photosynthetic rates of crop leaves, carbon dioxide assimilation and facilitates carbon movement (Abd El-Baky et al., 2010). Potassium expedites the transport of carbohydrates from the leaves to the tubers. Higher shoot: tuber ratios were found for plants treated with $\mathrm{KCl}$. The chloride functions as an osmotic ion as well as essential plant nutrient. Both potassium and nitrogen fertilization can influence tuber yield and quality.

\section{Materials and Methods}

The field experiment was conducted in College of Agriculture, Latur farm during the kharif season 2015-2016. This experiment was laid out in factorial randomized block design with 3 replications and 12 treatments. Experimental factors includes nitrogen fertilizer levels $(0,75,100,125 \mathrm{~kg} / \mathrm{ha})$ potassium fertilizer levels $(0,75,100)$ with 3 replications of different combination of levels. Total number of plots is 12 , size $3 \times 2$ sq. m with spacing $60 \times 20 \mathrm{~cm}$ with local variety. Graded levels of potassium and nitrogen was applied at the time planting and recommended dose of phosphorous was applied in the same time but graded levels of $\mathrm{N}$ was split in to half at time of planting and reaming half at the 30 days after planting.

Random Selection of five plants per plots for recorded the yield and yielding attributing, characters like tuber diameter, tuber length, number of tuber at the time of harvesting and quality parameters like fresh and dry weight of tubers, carbohydrates, reducing, non reducing and total sugar content, TSS, specific gravity, protein content was recorded at the harvesting stage of sweet potato by selected the five random tuber per plot. Data recorded on yield and quality parameter was subjected to analysis of variance (ANOVA, $p$ $\leq 0.05)$ and means comparisons were done at $P \leq 0.05$. Percentages were computed using the least square means from respective ANOVA and tables and figures were drawn using MS excel 2010 program.

Specific gravity $=\frac{\text { Weight of tuber in air }- \text { Weight of tuber }}{\text { Weight of tuber in air }}$ 


\section{Results and Discussion}

\section{Yield attributes}

The tuber yield of sweet potato was recorded highest $\left(22398 \mathrm{~kg} \mathrm{ha}^{-1}\right)$ in $125 \mathrm{~kg} / \mathrm{ha} \mathrm{N} \mathrm{N}_{3}$ and it was on par with $\mathrm{N}_{2}(100 \mathrm{~kg} / \mathrm{ha})$ and lowest tuber yield was recorded in $\mathrm{N}_{0}(11411 \mathrm{~kg} / \mathrm{ha})$. The tuber length of sweet potato $(18.58 \mathrm{~cm})$, diameter of tuber $(6.41 \mathrm{~cm})$ and number of tubers $\left(9.36\right.$ plant $\left.^{-1}\right)$ was found significantly highest in the level of $\mathrm{N}_{3} @ 125 \mathrm{~kg} / \mathrm{ha}$ and it was on par with $\mathrm{N}_{2}$ level @ $100 \mathrm{~kg} / \mathrm{ha}$ over control@0 kg/ha N (Table 1). This fertilizer effect might be due to application of higher dose of nitrogen would have helped in increases growth and higher supply of photosynthesis may increases the tuber weight, length diameter and number of tubers. Similar results were also observed by Sanjana et al., (2014) and Alfred et al., (2000).

Different levels of potassium fertilizer application, among this $\mathrm{K}_{2} @ 100 \mathrm{~kg} / \mathrm{ha} \mathrm{K}_{2} \mathrm{O}$ was recorded significantly highest sweet potato tuber yield $(19597 \mathrm{~kg} / \mathrm{ha})$ and it was on par with $\mathrm{K}_{1} @ 75 \mathrm{~kg} / \mathrm{ha}$ and lowest tuber yield noticed in control. The yield parameters like tuber length $(17.94 \mathrm{~cm})$, tuber diameter (5.96 $\mathrm{cm})$ and number of tuber $\left(9.0\right.$ plant $\left.^{-1}\right)$ was found significantly highest in the level of $\mathrm{K}_{2}$ @ $100 \mathrm{~kg} / \mathrm{ha}$ and it was on par with the $\mathrm{K}_{1}$ @ $75 \mathrm{~kg} / \mathrm{ha}$ over control showed in (Table 1). This might be due to positive response shown by yield characters to $\mathrm{K}$ could be directly linked by well development of photosynthetic and increased physiological activities leading to more assimilates and improved the translocation accumulation of sugars in development of tubers this was reported by Moniruzzamman et al., (2013).

The interaction effect (Table 2) of $\mathrm{N}$ and $\mathrm{K}$ was significant in the tuber diameter and yield of sweet potato. The $\mathrm{N}_{3} \times \mathrm{K}_{2}$ interaction shows significant effect on both tuber yield $(2326 \mathrm{~kg} / \mathrm{ha})$ and tuber diameter $(6.56 \mathrm{~cm})$ on par with $\mathrm{N}_{3} \times \mathrm{K}_{1}, \mathrm{~N}_{2} \times \mathrm{K}_{2}, \mathrm{~N}_{2} \times \mathrm{K}_{1}$ but significantly superior over rest of the interactions.

Lowest yield observed in $\mathrm{N}_{0} \times \mathrm{K}_{0}$ this might be due to the positive interaction between nitrogen and potassium in soil. Potassium influence on the crop yield can also be indirect as a result of its positive interaction with other nutrients especially nitrogen. Potassium along with nitrogen plays a major role in growth and yield as it is involved in assimilation, transport and storage at the time of photosynthesis and the effect of $\mathrm{N}$ : $\mathrm{K}$ interaction in cassava yield was reported by (Susan Johan et al., 2013). The increase in yield and size of tuber could not only by the effect of $\mathrm{K}$ fertilizer but also the combination of $\mathrm{N}, \mathrm{P}_{2} \mathrm{O}_{5}$ and high dose of organic manure was reported by Sridevi and Ramakrishna (2013).

\section{Quality attributes}

Regarding quality parameter of sweet potato the effect of different graded levels of nitrogen was significantly higher quality parameter (Table 3) like fresh tuber weight (451. $49 \mathrm{~g})$, dry tuber weight $(40.57 \mathrm{~cm})$, TSS $(13.37 \%)$, reducing sugar $(0.268 \%)$ non reducing sugar $(6.58 \%)$ and total sugar $(6.85$ $\mathrm{cm})$, carbohydrates $(18.01 \%)$ was recorded in $\mathrm{N}_{3}$ @ $125 \mathrm{~kg} / \mathrm{ha}$ followed by the rest of the treatments over the control $\mathrm{N}_{0}$. This might be due to nitrogen significantly increases sucrose contents, recoverable sugar yield adding to the highest level of nitrogen and association exists between uptake and accumulation of nutrient in tuber and also between their combined role in enhancing the synthesis of sucrose content and accumulation in tubers, similar results were reported by Patil et al., (1990) in sweet potato. 
Table.1 Effect of graded levels of nitrogen and potassium on yield attributes and yield of sweet potato

\begin{tabular}{|l|l|l|l|l|l|l|}
\hline $\begin{array}{l}\text { Treatments } \\
\text { (levels ) }\end{array}$ & $\begin{array}{l}\text { Length } \\
\text { of tuber } \\
(\mathrm{cm})\end{array}$ & $\begin{array}{l}\text { Diameter of } \\
\text { tuber }(\mathrm{cm})\end{array}$ & $\begin{array}{l}\text { Number } \\
\text { of tubers } \\
\text { per plant }\end{array}$ & $\begin{array}{l}\text { Weight of } \\
\text { tuber plot } \\
\left(\mathrm{kg} \mathrm{ha}^{-1}\right)\end{array}$ & $\begin{array}{l}\text { Yield } \\
\left(\mathrm{kg} \mathrm{ha}^{-}\right. \\
\left.1^{-}\right)\end{array}$ & $\begin{array}{l}\text { Dry } \\
\text { matter } \\
\text { tuber yield } \\
\mathrm{kg} \mathrm{ha}^{-1}\end{array}$ \\
\hline Nitrogen levels & & & & & & \\
\hline $\mathbf{N}_{\mathbf{0}}$ & 14.03 & 4.13 & 7.98 & 6.85 & 11411 & 4662.98 \\
\hline $\mathbf{N}_{\mathbf{1}}$ & 16.90 & 4.92 & 8.42 & 9.91 & 16518 & 5916.24 \\
\hline $\mathbf{N}_{\mathbf{2}}$ & 17.68 & 6.07 & 8.99 & 12.89 & 21496 & 7116.97 \\
\hline $\mathbf{N}_{\mathbf{3}}$ & 18.58 & 6.24 & 9.36 & 13.44 & 22398 & 6737.65 \\
\hline $\mathbf{S E} \pm$ & 0.46 & 0.13 & 0.25 & 0.24 & 407 & 216.08 \\
\hline $\mathbf{C D}$ @ 5\% & 1.35 & 0.38 & 0.73 & 0.72 & 1193 & 633.70 \\
\hline Potassium levels & & & & & & \\
\hline $\mathbf{K}_{\mathbf{0}}$ & 16.49 & 4.37 & 8.24 & 9.27 & 15447 & 5418.33 \\
\hline $\mathbf{K}_{\mathbf{1}}$ & 17.47 & 5.70 & 8.81 & 11.30 & 18825 & 6277.81 \\
\hline $\mathbf{K}_{\mathbf{2}}$ & 17.94 & 5.96 & 9.0 & 11.76 & 19597 & 6629.24 \\
\hline SE \pm & 0.40 & 0.11 & 0.21 & 0.21 & 352 & 187.14 \\
\hline $\mathbf{C D} @ \mathbf{5 \%}$ & 1.17 & 0.33 & 0.63 & 0.62 & 1033 & 548.80 \\
\hline $\begin{array}{l}\text { Interaction } \\
\text { (NxK) }\end{array}$ & & & & & & \\
\hline SE \pm & 0.80 & 0.22 & 0.43 & 0.42 & 705 & 374.27 \\
\hline CD@ 5\% & $\mathrm{NS}$ & 0.65 & $\mathrm{NS}$ & 1.24 & $\mathrm{~S}$ & $\mathrm{NS}$ \\
\hline
\end{tabular}

NS = Non significance, $S=$ Significance

Table.2 Interaction effects of graded levels of nitrogen and potassium on tuber yield of sweet potato

\begin{tabular}{|l|c|c|c|c|}
\hline Levels & $\mathbf{K}_{\mathbf{0}}$ & $\mathbf{K}_{\mathbf{1}}$ & $\mathbf{K}_{\mathbf{2}}$ & Mean \\
\hline $\mathbf{N}_{\mathbf{0}}$ & 6944 & 12977 & 14311 & 11411 \\
\hline $\mathbf{N}_{\mathbf{1}}$ & 13983 & 17277 & 18294 & 16518 \\
\hline $\mathbf{N}_{\mathbf{2}}$ & 20044 & 21922 & 22522 & 21496 \\
\hline $\mathbf{N}_{\mathbf{3}}$ & 20811 & 23122 & 23261 & 22398 \\
\hline $\mathbf{M e a n}$ & 15445 & 18825 & 19597 & \\
\hline & $\mathbf{S E} \pm$ & C.D. @ 5 \% & & \\
\hline $\mathbf{N}$ & 407 & 1193 & & \\
\hline $\mathbf{K}$ & 352 & 1034 & & \\
\hline Interaction (NxK) & 705 & 2067 & & \\
\hline
\end{tabular}

NS = Non significance, $\mathrm{S}=$ Significance 
Table.3 Effect of graded levels of nitrogen and potassium on quality parameters of sweet potato

\begin{tabular}{|l|l|l|l|l|l|l|l|l|}
\hline Treatments & $\begin{array}{l}\text { Fresh } \\
\text { tuber } \\
\text { weight } \\
\text { g) }\end{array}$ & $\begin{array}{l}\text { Dry } \\
\text { weight of } \\
\text { tuber(g) }\end{array}$ & $\begin{array}{l}\text { TSS } \\
\text { (Brix) }\end{array}$ & $\begin{array}{l}\text { Reducing } \\
\text { sugar }(\%)\end{array}$ & $\begin{array}{l}\text { Non } \\
\text { reducing } \\
\text { sugar } \\
(\%)\end{array}$ & $\begin{array}{l}\text { Total } \\
\text { sugar (\%) }\end{array}$ & $\begin{array}{l}\text { Carbohydrat } \\
\text { es (\%) }\end{array}$ & $\begin{array}{l}\text { Specific } \\
\text { gravity } \\
\left(\mathrm{gml}^{-1}\right)\end{array}$ \\
\hline $\begin{array}{l}\text { Nitrogen } \\
\text { levels }\end{array}$ & & & & & & & & \\
\hline N0 & 271.10 & 32.84 & 11.52 & 0.167 & 4.57 & 4.74 & 15.71 & 1.14 \\
\hline N1 & 365.51 & 34.07 & 11.96 & 0.192 & 5.74 & 5.93 & 16.01 & 1.096 \\
\hline N2 & 422.03 & 39.18 & 12.79 & 0.241 & 5.83 & 6.07 & 17.55 & 1.065 \\
\hline N3 & 451.49 & 40.57 & 13.37 & 0.268 & 6.58 & 6.85 & 18.01 & 1.04 \\
\hline SE \pm & 11.24 & 0.429 & 0.189 & 0.004 & 0.086 & 0.085 & 0.288 & 0.014 \\
\hline CD@ 5\% & 32.96 & 1.26 & 0.555 & 0.011 & 0.253 & 0.251 & 0.844 & 0.040 \\
\hline $\begin{array}{l}\text { Potassium } \\
\text { levels }\end{array}$ & & & & & & & & \\
\hline K0 & 339.74 & 36.06 & 12.03 & 0.202 & 5.11 & 5.31 & 16.33 & 1.07 \\
\hline K1 & 375.85 & 36.55 & 12.47 & 0.218 & 5.70 & 5.92 & 16.85 & 1.07 \\
\hline K2 & 410.26 & 37.39 & 12.69 & 0.231 & 6.23 & 6.46 & 17.29 & 1.12 \\
\hline SE \pm & 9.73 & 0.37 & 0.164 & 0.003 & 0.075 & 0.074 & 0.249 & 0.012 \\
\hline CD@ 5\% & 28.55 & 1.090 & 0.481 & 0.009 & 0.219 & 0.217 & 0.731 & 0.035 \\
\hline $\begin{array}{l}\text { Interaction } \\
\text { (NxK) }\end{array}$ & & & & & & & & \\
\hline SE \pm & 19.47 & 0.743 & 0.328 & 0.006 & 0.149 & 0.148 & 0.498 & 0.024 \\
\hline CD@ 5\% & NS & NS & NS & NS & NS & NS & NS & NS \\
\hline
\end{tabular}

NS = Non significance, $\mathrm{S}=$ significance

Fig.1 Effect of graded levels of nitrogen and potassium on sweet potato yield $\left(\mathrm{kg} \mathrm{ha}^{-1}\right)$

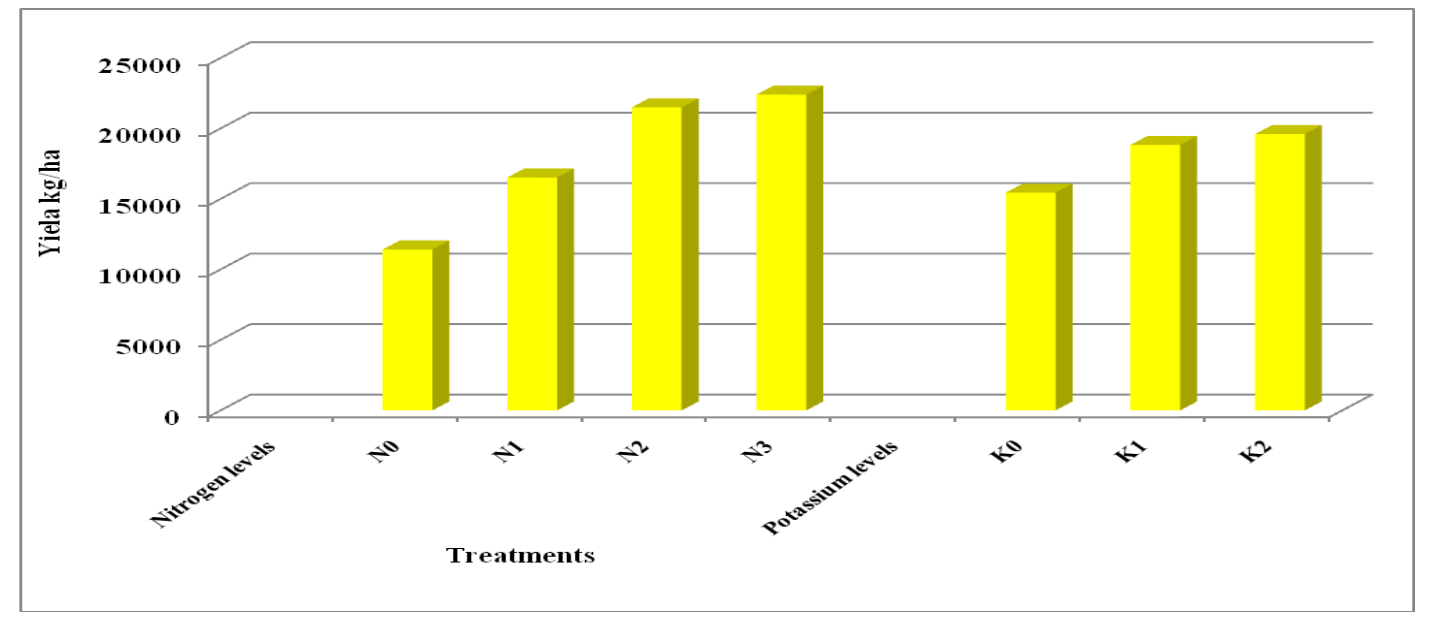


Fig.2 Length of tubers as influenced by graded levels of nitrogen and potassium

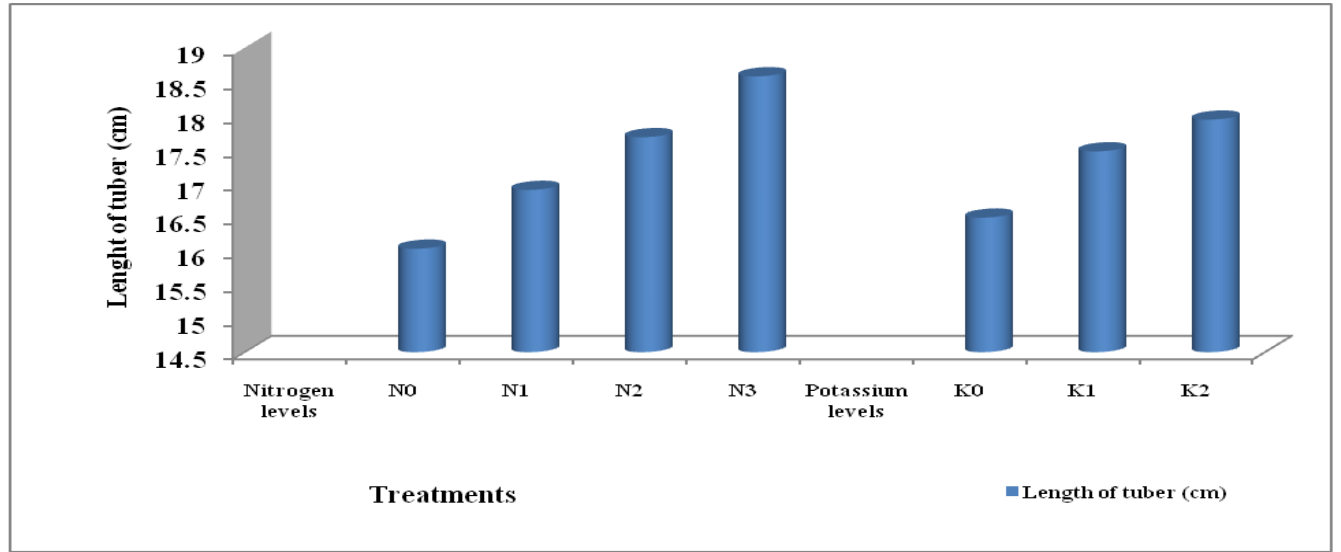

Fig.3 Diameter of tubers as influenced by graded levels of nitrogen and potassium

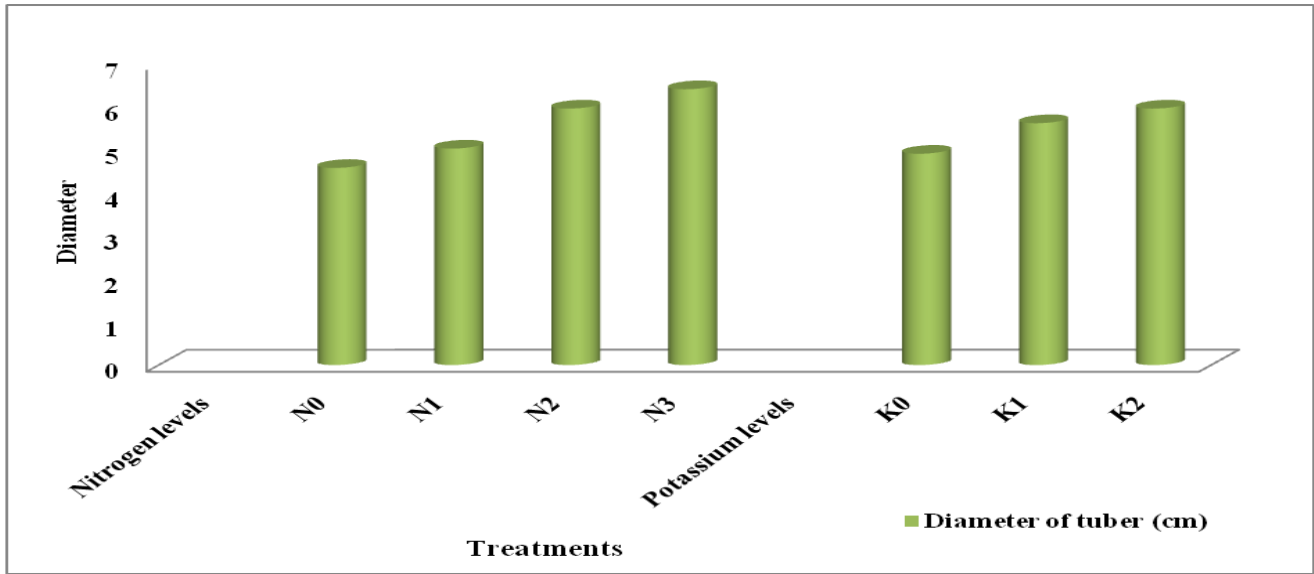

Fig.4 Sugar content of tuber as influenced by graded levels of nitrogen and Potassium (\%)

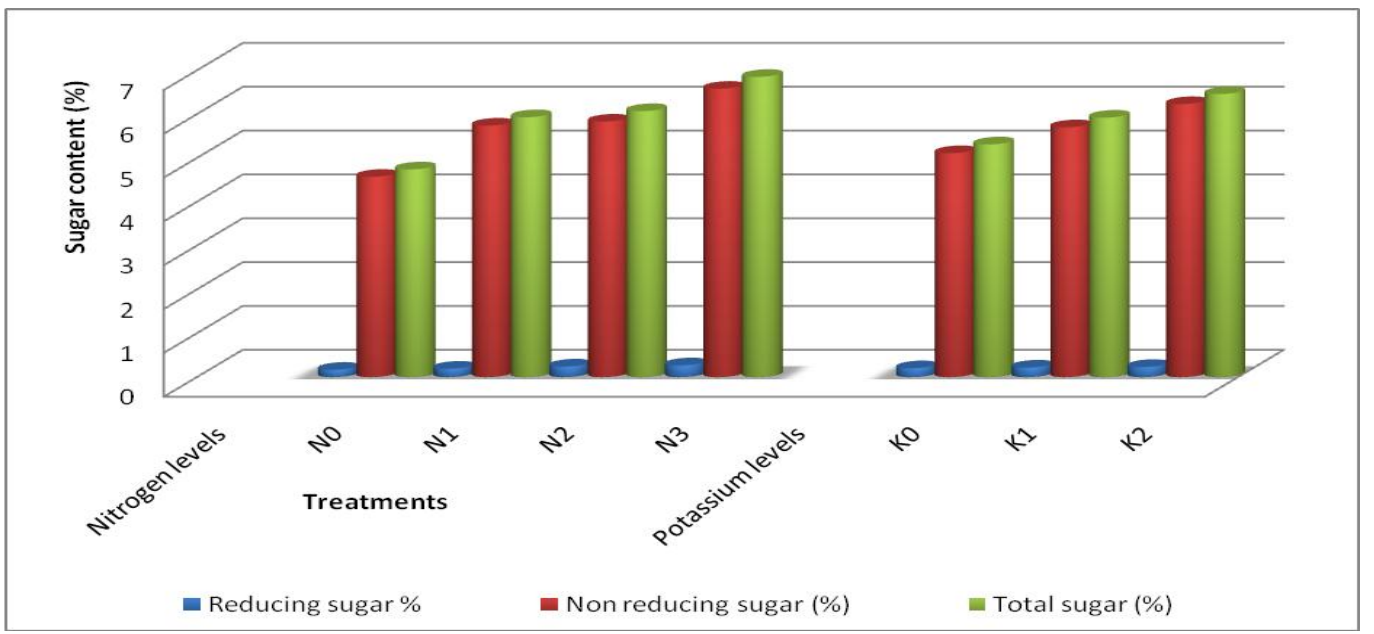


Fig.5 TSS content of tuber as influenced by graded levels of N and K

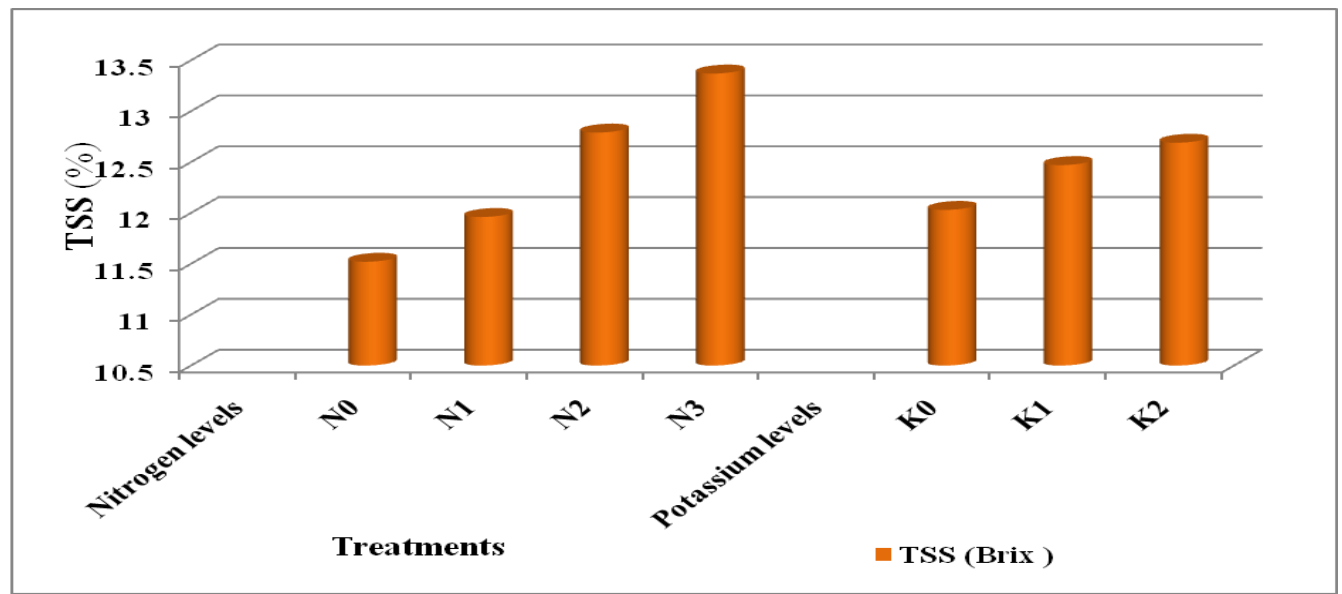

Effect of graded levels of potassium were significantly influenced on quality parameters (Table 3) viz. fresh tuber weight (410.26 g), dry tuber weight $(37.39 \mathrm{~cm})$, TSS $(12.69 \%)$, reducing sugar $(0.232 \%)$ non reducing sugar $(6.23 \%)$ and total sugar $(6.46 \mathrm{~cm})$, carbohydrates ( $17.29 \%$ ) was found in $\mathrm{K}_{2} @$ $100 \mathrm{~kg} / \mathrm{ha} \mathrm{K}_{2} \mathrm{O}$ followed by rest of the treatments over the control $\mathrm{K}_{0}$. Specific gravity of sweet potato tuber was significantly increase with decreases the levels of nitrogen fertilizer may be due to effect of higher dose of graded levels of nitrogen reduces the specific gravity of tubers influence of $\mathrm{N}$ on gibberellins biosynthesis and other phytohormonal activities which have direct influence on plant growth and dry matter accumulation same result was recorded by Mehran and Samod (2013), they observed that, the nitrogen significantly increases sucrose contents, recoverable sugar yield adding to the highest level of nitrogen $(285 \mathrm{~kg}$ $\mathrm{N} \mathrm{ha-1}$ ) in sugar beet crop. Potassium application there is significant increases with increases the specific gravity of tubers. The interaction between the different levels of fertilizers doesn't show any significant interaction in quality parameters (Figs 1-5).

In conclusion, from the result and discussion of this study can be concluded that the achieving higher yield and yield attributing characters and improved quality parameters of sweet potato crop should be fertilized with $125 \mathrm{Kg} \mathrm{N}^{-1}{ }^{-1}$ and $100 \mathrm{Kg} \mathrm{K}_{2} \mathrm{O} \mathrm{ha}^{-1}$. But in specific gravity of sweet potato was observed increases the nitrogen fertilization decrease the specific gravity of sweet potato.

\section{Acknowledgement}

The work was supported by department of Soil Science and Agricultural Chemistry and Deportment of Horticulture, College of Agriculture Latur, Vasanth Roa Naik Marathwad Krishi Vidyapeet, Parbani (M H), India. We are thankful to Dr. P.H. Vaidy, and P.B. Adsul, for their assistance in the completion of this research work.

\section{References}

Abd El-Baky, M.M.H., Ahmed, A.A., ElNemr, M.A. and Zaki, M.F. 2010. Effect of potassium fertilizer and foliar zinc application on yield and quality of sweet potato. Res. J. Agri. Biol. Sci., 6(4): 386-394.

Alfred, E., Hartemink, A.M. Johnston, J.N. O'Sullivanc, S. Polomad. 2000. Nitrogen use efficiency of taro and sweet potato in the humid lowlands of 
Papua New Guinea. Agri. Ecosystems and Environ., 79: 271-280.

FAO and IFA. 2000. "Fertilizers and their use". A pocket guide for extension officers. 4th. Ed. food and agriculture organization of the united nations International Fertilizer Industry Association, Rome.

Moniruzzaman, M., Akand, M.H., hossain, M.I., Sarkar, M.D., and Ullah, A. 2013. Effect of nitrogen on the growth and yield of carrot (Daucuscarota L.). A Scientific J. Krishi Foundation, 11(1): 76-81.

Patil, Y.B., Patil, A.A., Hilmani, N.C., and Patil, V.S. 1990 influence of varying levels of nitrogen, potassium and interRow spacing on certain quality attributes of sweet potato. Karnataka J. Agri. Sci., 3 (4): 281- 285.

Sanjana Banjare, Gaurav Sharma and Verma, S.K. 2014. Potato crop growth and yield response to different levels of nitrogen under Chhattisgarh plains agro-climatic zone. Indian J. Sci. Technol., Vol 7(10): 1504-1508.
Sridevi, S. and Ramakrishnan, K. 2013. Effect of inoculation with NPK fertilizer and arbuscularmycorrhizal fungi on growth and yield of cassava. Int. J. Develop. Res., Vol. 3, Issue, 9. Pp.046-050.

Susan John, K., Ravindran, C.S. James George, M. Manikantan Nair and Suja, G. 2013. Potassium. a key nutrient for high tuber yield and better tuber quality in cassava. Better Crops - South Asia, 2(2): $26-27$.

Uwah, D.F., Undie, U.L., John, N.M. and Ukoha, G.O. 2013. Growth and yield response of improved sweet potato (Ipomoea batatas (L.) Lam) varieties to different rates of potassium fertilizer in Calabar, Nigeria. J. Agri. Sci., 5(7): 230-242.

Ukom, A.N., Ojimelukwe, P.C. and Okpara, D.A. 2009. Nutrient composition of selected sweet potato [Ipomea batatas (L) Lam] varieties as influenced by different levels of nitrogen fertilizer application, Pak. J. Nutri., 8(11): 17911795, ISSN 1680-5194.

\section{How to cite this article:}

Pushpalatha, M., P.H. Vaidya and Adsul, P.B. 2017. Effect of Graded Levels of Nitrogen and Potassium on Yield and Quality of Sweet Potato (Ipomoea batatas L.). Int.J.Curr.Microbiol.App.Sci. 6(5): 1689-1696. doi: https://doi.org/10.20546/ijcmas.2017.605.183 